\title{
Epidemiologi Demam Berdarah Dengue di Kabupaten Minahasa Sulawesi Utara
}

\author{
Oksfriani Jufri Sumampouw
}

Fakultas Kesehatan Masyarakat Universitas Sam Ratulangi Manado

E-mail: oksfriani.sumampouw@unsrat.ac.id

\begin{abstract}
Background: Dengue hemorrhagic fever (DHF) was a health problem in North Sulawesi Province, especially in the Minahasa Regency. DHF was a multifactorial disease. The purpose of this study were to describe the distribution of DHF patients in Minahasa Regency in 20162018. This research was an observational study. Method: This research was conducted in MayJuly 2019 in Minahasa Regency. The research variables were gender, age and DHF cases. The data used were secondary data from the Minahasa District Health Office. Data were analyzed univariately. Results: The results showed that DHF sufferers at the age of 11-20 years (58 cases). Most DHF sufferers were found in women (83 cases). The incidence of DHF in 20162018 has increased by 94 cases. There was a time shift in the occurrence of DHF in 2018. In 2018, many DHF events occurred in August-October. Conclusion: The conclusion of this study was that most DHF sufferers in 11-20 years and female. In addition, there has been a shift in the pattern of dengue fever in Minahasa Regency.
\end{abstract}

Keywords: Dengue Hemorrhagic Fever, Age, Sex, Minahasa Regency

\section{PENDAHULUAN}

Deman Berdarah Dengue (DBD) merupakan penyakit demam akut yang disebabkan oleh virus dengue serta memenuhi kriteria World Health Organization (WHO) untuk DBD. DBD adalah salah satu manifestasi simptomatik (yang menimbulkan gejala) dari infeksi virus dengue yang dapat menyerang semua golongan umur, walaupun sampai saat ini DBD lebih banyak menyerang anak-anak. Namun, dalam dekade terakhir ini terlihat kecenderungan yang meningkat pada kelompok dewasa (Sofro dan Anurogo 2018).

Deman Berdarah Dengue pada saat ini merupakan penyebab utama rawat inap di rumah sakit. Selain itu, DBD merupakan penyebab kematian tertinggi pada anak-anak di kawasan Asia Tenggara. Dengan adanya perubahan iklim maka menyebabkan prevalensi DBD semakin tinggi (Sumampouw, 2019). Indonesia merupakan salah satu negara Asia Tenggara yang paling banyak melaporkan kejadian DBD. Berdasarkan data yang diperoleh, infeksi DBD di Indonesia lebih banyak diderita oleh kelompok dewasa muda. Pada tahun 2000, terjadi epidemi DBD di Indonesia. Sekitar $82 \%$ penderita DBD 
yang rawat inap di rumah sakit merupakan orang dewasa. Namun, kasus kematian semua dialami oleh penderita berumur di bawah 5 tahun (Soedarto, 2012).

Provinsi Sulawesi Utara merupakan salah satu wilayah yang mempunyai resiko yang tinggi dalam kejadian penyakit DBD. Data dari Dinas Kesehatan Provinsi Sulawesi Utara menyebutkan bahwa prevalensi DBD pada tahun 2016 sebesar 2.217 kasus. Jumlah ini meningkat jika dibanding dengan tahun 2015 (1562 kasus). Selain itu, jumlah penderita yang meninggal pada tahun 2016 sebanyak 17 orang. Pada tahun 2016, terjadi Kejadian Luar Biasa (KLB) di beberapa kabupaten/kota se-Sulut. Kabupaten/ kota tersebut yaitu Kota Manado (jumlahnya 3 kali dari tahun 2015), Kabupaten Minahasa Utara (jumlahnya 2 kali dari tahun 2015), Kabupaten Minahasa, Bolaang dan Mongondow Utara (jumlahnya 1 kali dari tahun 2015). Data yang diperoleh dari Dinas Kesehatan (Dinkes) Provinsi Sulawesi Utara, ditemukan sejak tahun 2009-2018, prevalensi DBD meningkat sebesar 741 kasus atau rata-rata peningkatan sebesar 185 kasus per tahun (Dinkes Sulut, 2018).

Demam Berdarah Dengue disebabkan oleh beberapa faktor risiko seperti faktor lingkungan, pelayanan kesehatan dan manusia. Faktor manusia terdiri dari jenis kelamin, umur dan lainnya. Menurut Ginanjar (2012), umumnya penyakit DBD lebih banyak menyerang anak-anak karena kecenderungan waktu main anak-anak yaitu di dalam ruang. Kasus DBD beberapa tahun terakhir seringkali muncul di musim pancaroba, khususnya bulan Januari (awal tahun). Penyebaran dan tinggi rendahnya prevalensi DBD dipengaruhi oleh beberapa faktor seperti tinggi rendahnya populasi vektor, virulensi virus, imunitas penduduk, karakteristik penduduk, kepadatan penduduk, mobilitas penderita, kemampuan virus memperbanyak diri dalam tubuh nyamuk dan perilaku manusia yang dapat memberi peluang terjadinya angka kejadian DBD (Fitriani, 2011).

Kabupaten Minahasa merupakan salah satu kabupaten di Sulawesi Utara. Kabupaten Minahasa merupakan salah satu daerah yang bermasalah dengan DBD. Data yang diperoleh dari Dinas Kesehatan Kabupaten Minahasa ditemukan adanya peningkatan jumlah signifikan sebanyak 94 kasus sejak 2016-2018. Pada tahun 2016, Kabupaten Minahasa dinyatakan terjadi KLB DBD. Tujuan penelitian ini yaitu untuk menggambarkan distribusi penderita DBD di Kabupaten Minahasa (tahun 2016-2018) berdasarkan waktu kejadian, umur dan jenis kelamin.

\section{METODE PENELITIAN}

Penelitian ini merupakan penelitian observasional. Penelitian di lakukan di Kabupaten Minahasa. Variabel yang dibahas yaitu waktu kejadian penyakit DBD, jenis kelamin penderita dan kelompok umur penderita DBD. Data yang digunakan diperoleh dari Dinas Kesehatan Kabupaten Minahasa. Data yang diperoleh selanjutnya dianalisis secara univariat dan ditampilkan dalam bentuk grafik.

\section{HASIL DAN PEMBAHASAN}

\section{Distribusi penderita DBD berdasarkan kelompok umur}

Distribusi penderita DBD di Kabupaten Minahasa tahun 2016-2018 berdasarkan kelompok umur dapat dilihat pada Gambar 1 dan 2. 


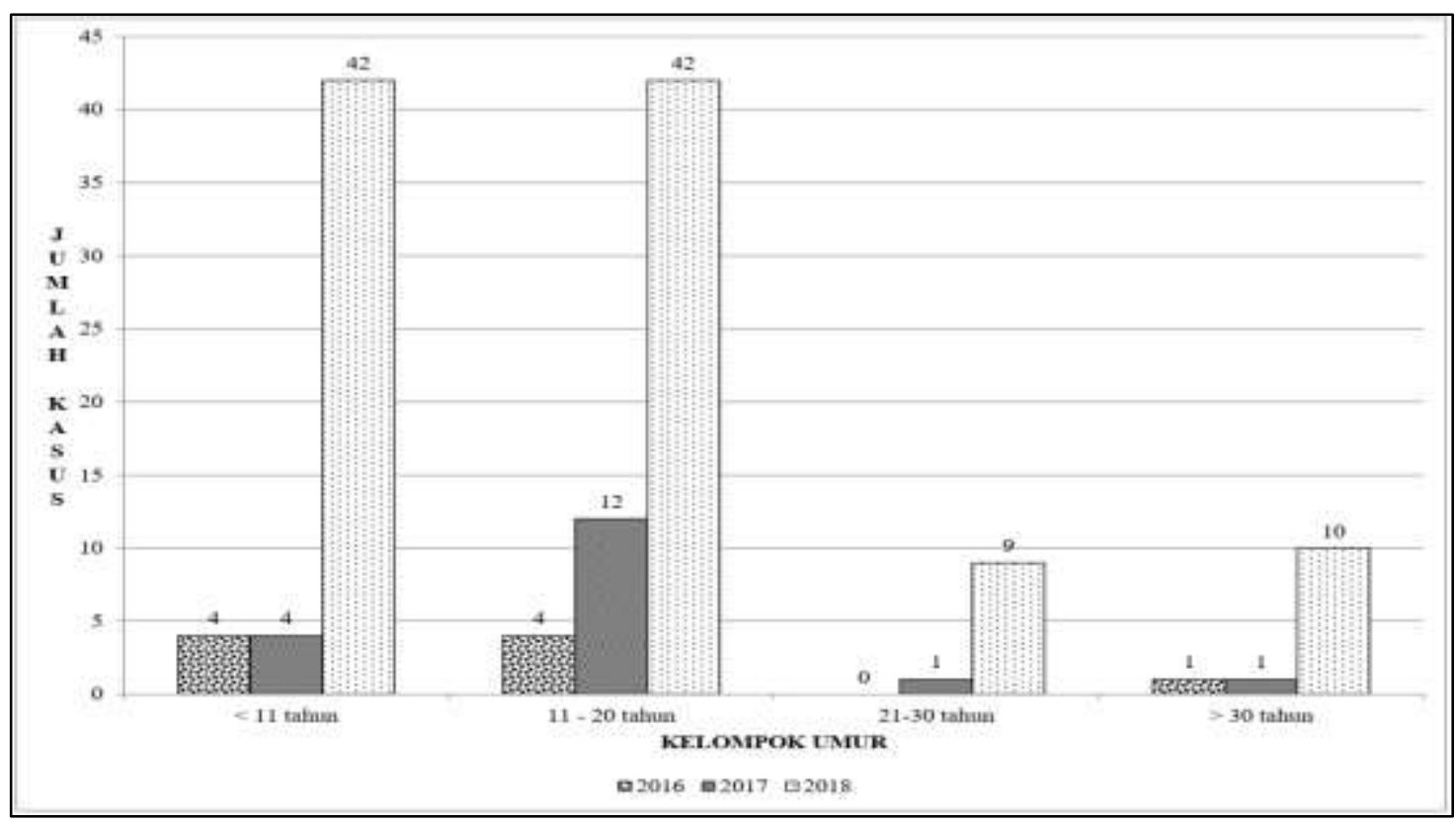

Gambar 1. Distribusi penderita DBD berdasarkan kelompok umur per tahun

Gambar 1 menunjukkan bahwa pada tahun 2016, paling banyak ditemukan pada umur < 11 tahun dan 11-20 tahun masing-masing sebanyak 4 kasus. Pada tahun 2017, kasus DBD paling banyak terjadi pada umur 11-20 tahun sebanyak 12 kasus. Pada tahun 2018, kasus DBD paling banyak terjadi pada umur $<11$ tahun dan 11-20 tahun masingmasing sebanyak 42 kasus.

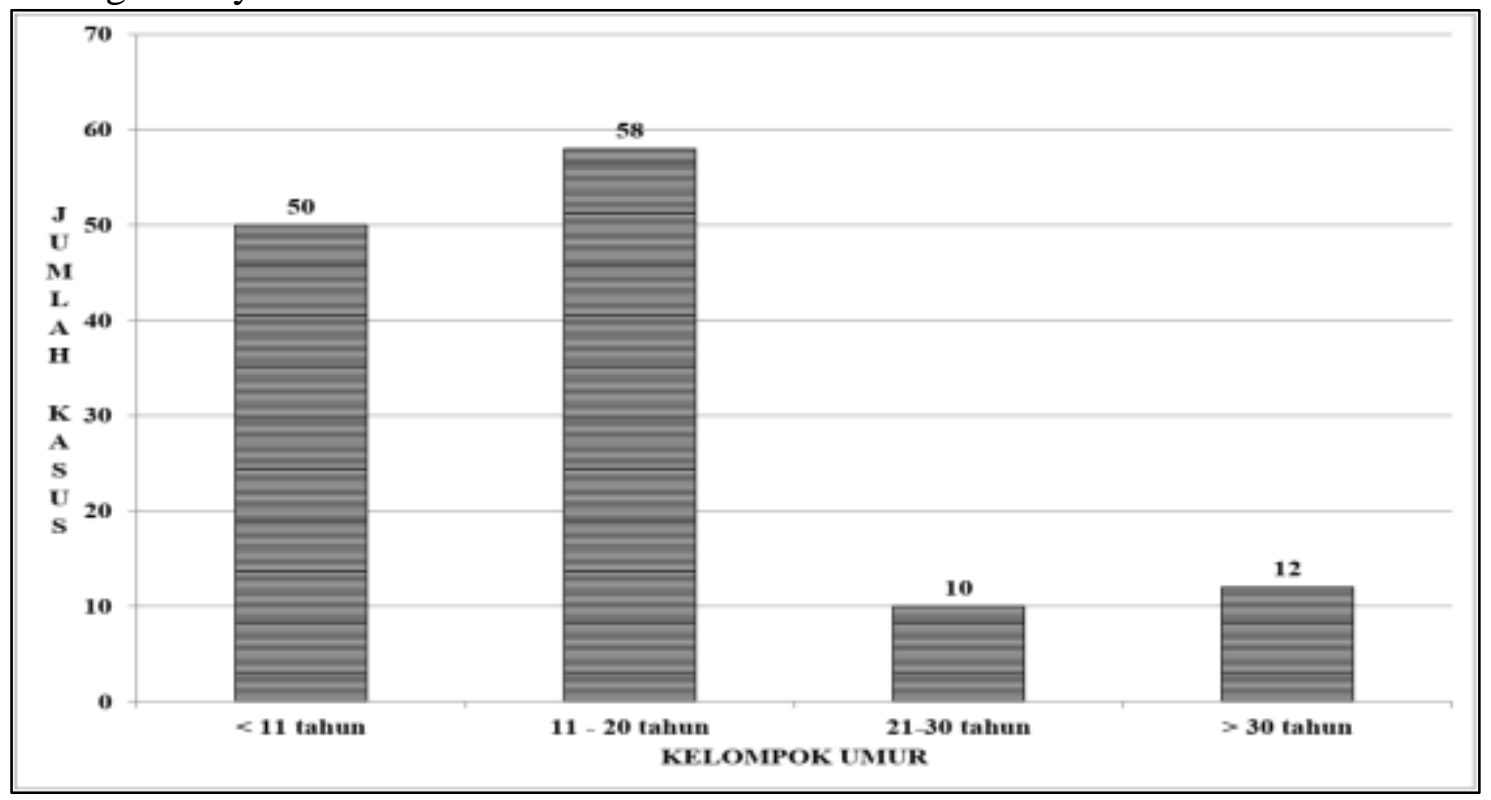

Gambar 2. Distribusi penderita DBD berdasarkan kelompok umur

Gambar 2 menunjukkan bahwa pada tahun 2016-2018 paling banyak penderita DBD pada umur 11-20 tahun sebanyak 58 kasus. Penelitian dari Dardjito et al (2008) yang dilakukan dengan design penelitian kasus kontrol menunjukkan bahwa faktor risiko DBD salah satunya yaitu umur.

Menurut Sumarmo (1999) pada awal terjadinya wabah di suatu negara distribusi umur memperlihatkan jumlah penderita terbanyak dari golongan anak berumur kurang dari 15 tahun (86-95\%). Namun pada wabah-wabah selanjutnya, jumlah penderita yang digolongkan dalam golongan umur dewasa muda meningkat. Di Indonesia penderita DBD terbanyak adalah anak dengan umur 5-11 tahun. Hasil penelitian Simanjuntak (2015), menunjukkan bahwa variabel yang bermakna sebagai faktor yang meningkatkan 
risiko kejadian DSS pada penderita DBD yaitu umur $<15$ tahun. Penelitian yang dilakukan Mandriani (2009) mengenai karakteristik penderita DBD yang mengalami DSS di RSUD Dr. Pirngadi Medan tahun 2008 didapati bahwa proporsi penderita tertinggi pada kelompok umur 10-14 tahun.

Selanjutnya, penelitian dari Arifin et al (2017) menunjukkan bahwa sebaran kasus kejadian DBD di Kota Tanjungpinang tahun 2016 sebagian besar (34,2\% ) terjadi pada usia 5-9 tahun. Hasil penelitian dari Dardjito et al (2008) menunjukkan bahwa kasus DBD lebih banyak terjadi pada rata-rata umur $<12$ tahun jika dibandingkan dengan umur > 12 tahun. Hal ini didukung oleh kebiasaan masyarakat bahwa anak-anak kebanyakan aktivitasnya berada di dalam rumah, sehingga kemungkinan kontak dengan nyamuk Aedes aegypti lebih besar dibandingkan dengan orang dewasa muda maupun orang tua kebanyakan aktivitasnya di luar rumah.

Hasil penelitian dari Permatasari et al (2013) menunjukkan bahwa berdasarkan uji statistik menunjukkan bahwa tidak ada hubungan yang signifikan antara umur dengan derajat infeksi dengue. Hasil ini menunjukkan bila pembentukan antibodi spesifik terhadap antigen sudah sempurna maka tubuh memiliki imunitas yang tinggi untuk melawan infeksi virus. Tidak semua anak umur $<5$ tahun memiliki imunitas yang rendah sehingga rentan terhadap penyakit.

Penelitian dari Nelli (2007) dan Hakim dan Kusnandar (2012) menemukan bahwa respon imun dengan spesifitas dan memori imunologik yang tersimpan dalam sel dendrit dan kelenjar limfe belum sempurna. Selain itu, fungsi makrofag dan pembentukan antibodi spesifik terhadap antigen tertentu masih kurang. Sehingga sekresi sitokin oleh makrofag akibat infeksi virus kurang yang menyebabkan kurangnya produksi interferon (IFN) yang berfungsi menghambat replikasi virus dan mencegah penyebaran infeksi ke sel yang belum terkena.

\section{Distribusi penderita DBD berdasarkan jenis kelamin}

Distribusi penderita DBD di Kabupaten Minahasa tahun 2016-2018 dapat dilihat pada Gambar 3 dan 4.

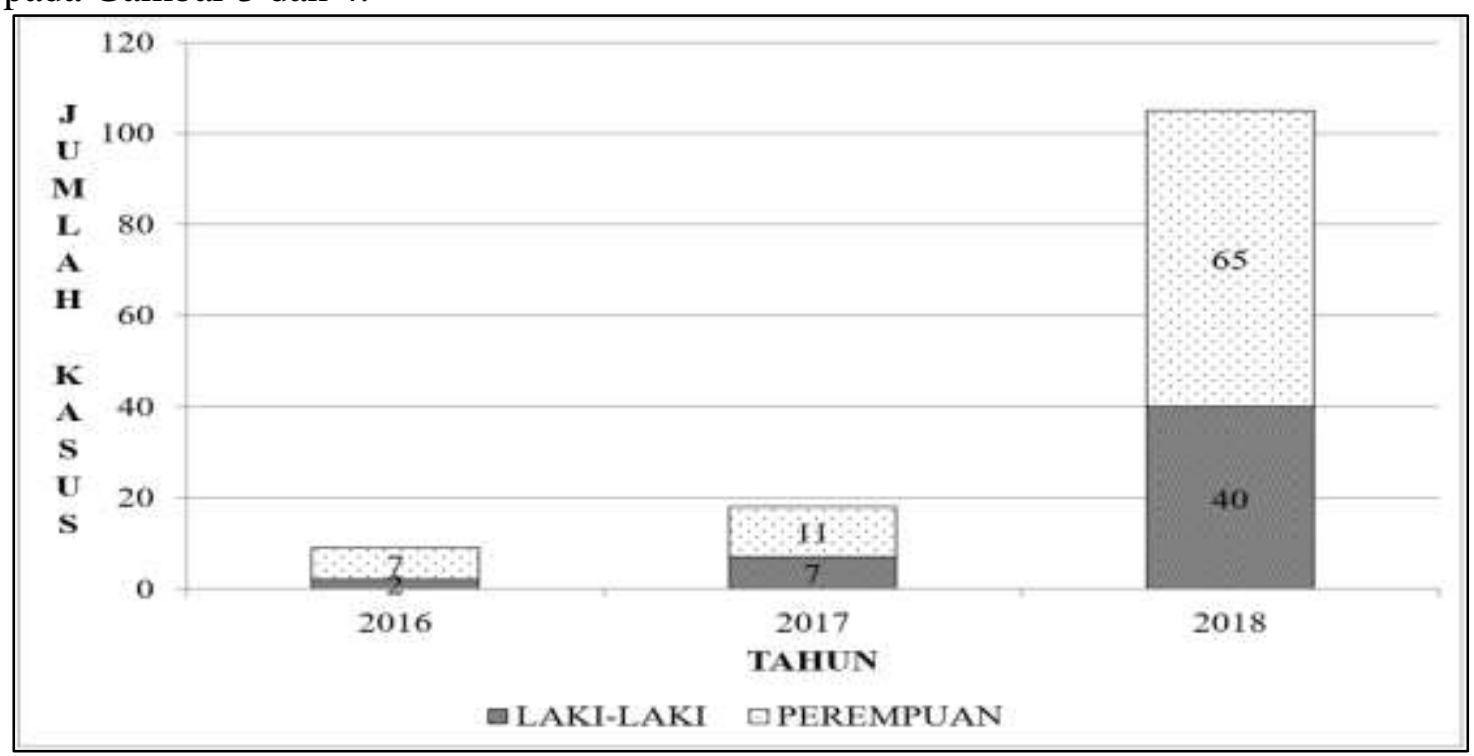

Gambar 3. Distribusi penderita DBD berdasarkan jenis kelamin per tahun

Gambar 3 menunjukkan bahwa pada tahun 2016-2018, paling banyak ditemukan pada perempuan yaitu 7 kasus (2016), 11 kasus (2017) dan 65 kasus (2018). 


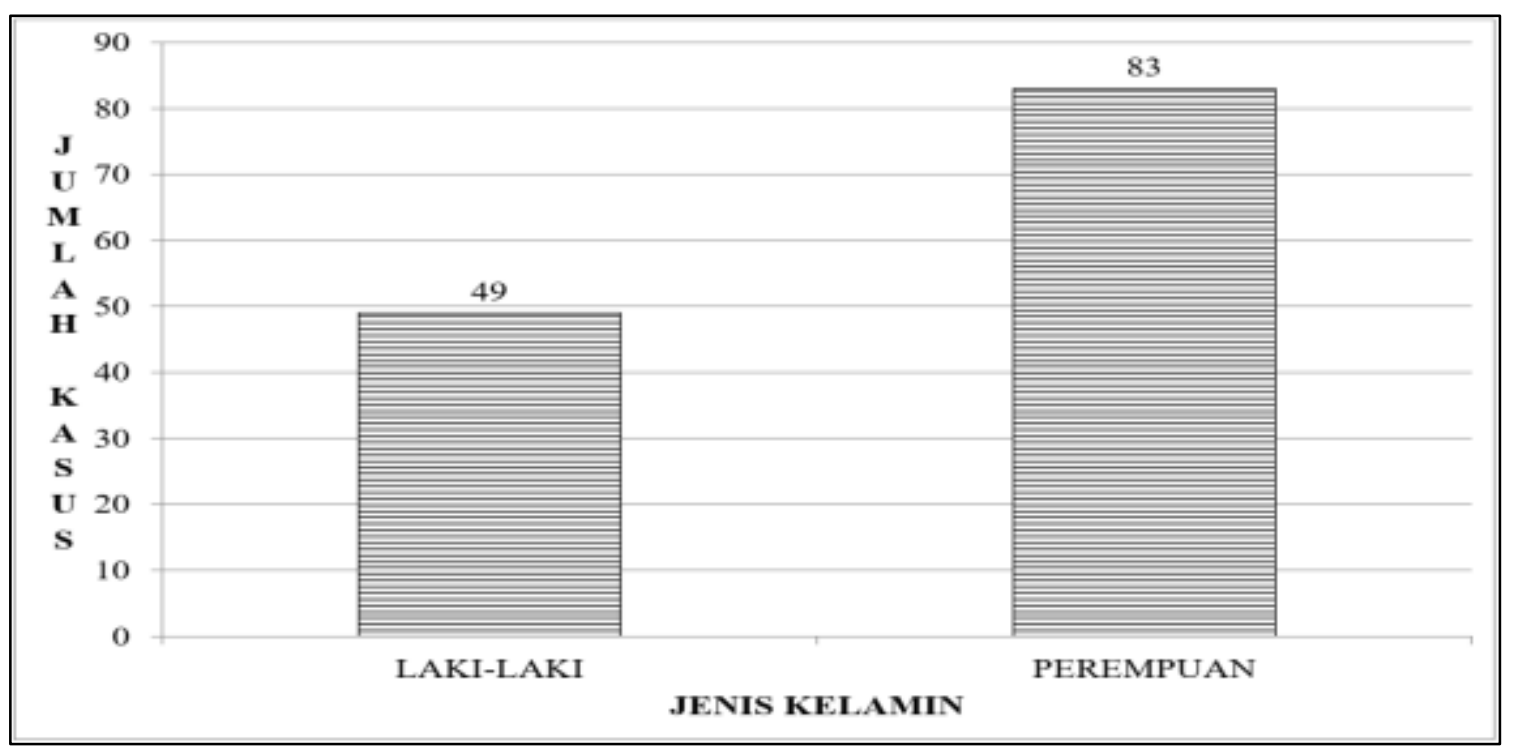

Gambar 4. Distribusi penderita DBD berdasarkan jenis kelamin

Gambar 4 menunjukkan bahwa pada tahun 2016-2018, kasus DBD paling banyak ditemukan pada perempuan yaitu sebanyak 83 kasus. Hasil penelitian ini sejalan dengan penelitian dari Anders et al (2011), dimana kasus DBD memiliki risiko yang lebih tinggi pada perempuan. Penelitian dari Permatasari et al (2013) juga menunjukkan bahwa berdasarkan hasil uji statistik yang menilai hubungan jenis kelamin anak dengan DBD menunjukkan bahwa ada hubungan yang signifikan antara jenis kelamin dengan DBD. Responden perempuan memiliki peluang 3,333 kali lebih besar menderita DBD daripada laki-laki.

Penelitian dari Arifin (2017) menunjukkan bahwa sebaran kasus DBD lebih dominan pada jenis kelamin perempuan tahun 2016 proporsi pada perempuan sebesar $50,3 \%$ dan tidak berbeda jauh dengan proporsi pada laki-laki yaitu 49,7\% .

Hal ini sesuai dengan penelitian sebelumnya bahwa jenis kelamin merupakan salah satu faktor resiko DBD dengan renjatan atau tanpa renjatan. Faktor keturunan yang terkait jenis kelamin dan faktor hormonal mempengaruhi angka kematian penderita DBD. Hormon glikoprotein mempengaruhi perkembangan sel fagosit mononuklear dan sel granulosit sebagai respon pertahanan tubuh (Soedarmo et al, 2008; Riyanto, 2011; Akib et al 2008; Supariasa et al 2012; Batubara et al 2010).

Kerja hormon dipengaruhi oleh adanya protein spesifik yang disebut reseptor. Reseptor hormon glikoprotein yaitu folicle stimulating hormone (FSH) dan luteinizing hormone (LH) terdapat di membran plasma sel gonad. Aktivasi FSH dan LH yang dipengaruhi hipotalamus dapat ditekan oleh steroid gonad sehingga pada anak hormon estrogen sangat rendah. Estrogen mempengaruhi penimbunan lemak di tubuh. Sehingga rendahnya estrogen pada anak perempuan menyebabkan leptin yang dihasilkan oleh sel lemak dalam tubuh masih sedikit. Leptin merupakan protein hormon yang mengatur berat badan. Sehingga anak perempuan cenderung memiliki berat badan kurang dengan imunitas rendah akan rentan terhadap penyakit karena memiliki imunitas selular rendah sehingga respon imun dan memori imunologik belum berkembang sempurna. Pada status gizi buruk/kurang terjadi penurunan imunitas dengan berkurangnya jumlah sel Thelper dan terganggunya fagositosis serta memori imunologik belum sempurna sehingga pusat respon imun tubuh yaitu limfosit $T$ tidak dapat memproduksi sitokin dan mediator sebagai pertahanan tubuh (Soedarmo et al, 2008; Riyanto, 2011; Akib et al 2008; Supariasa et al 2012; Batubara et al 2010). 
Distribusi penderita DBD di Kabupaten Minahasa tahun 2016-2018 berdasarkan waktu kejadian 5 dan 6.

Distribusi penderita DBD berdasarkan waktu kejadian dapat dilihat pada Gambar

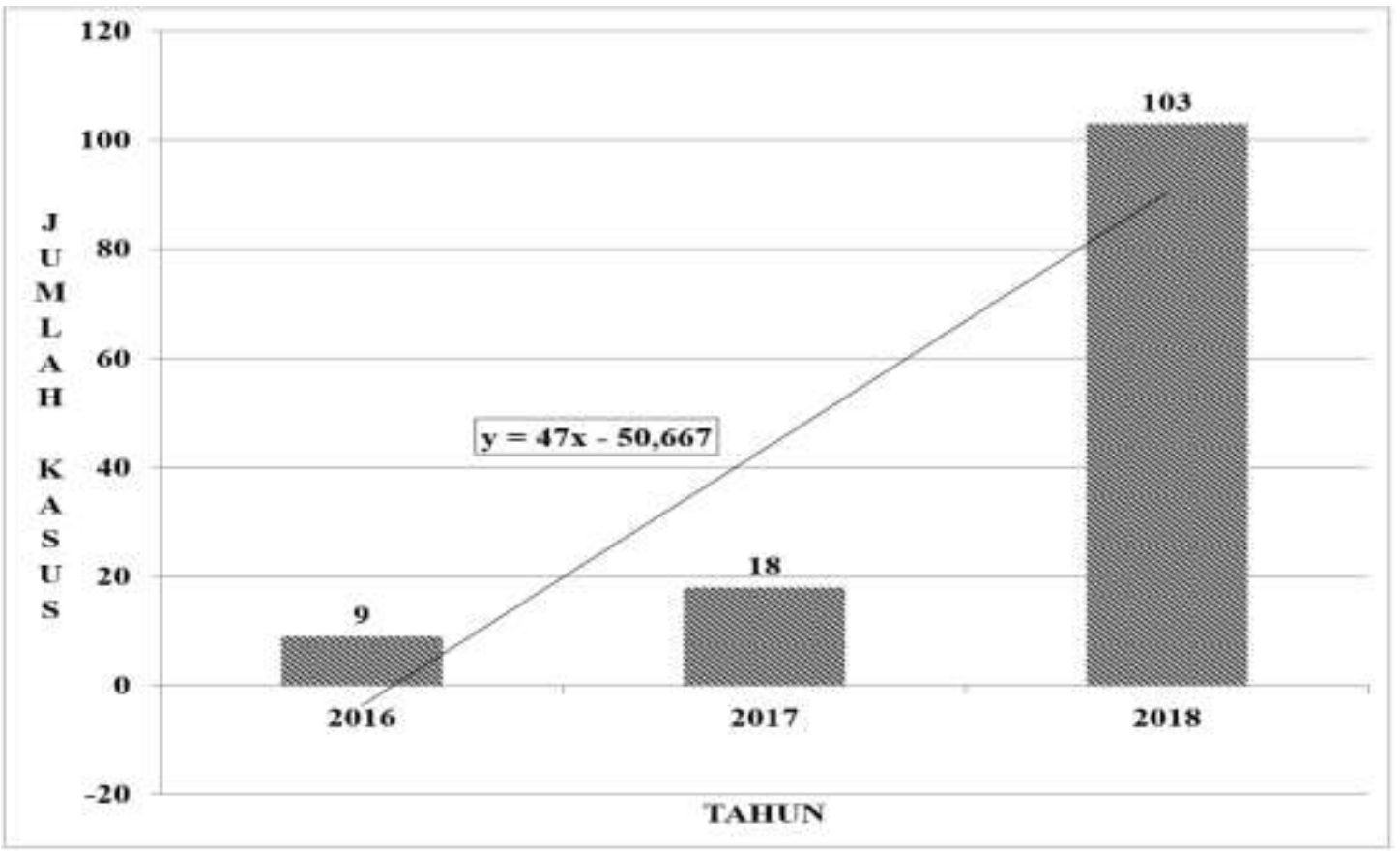

Gambar 5. Distribusi penderita DBD per tahun

Gambar 5 menunjukkan bahwa pada tahun 2016-2018 kasus DBD mengalami peningkatan sebesar 94 kasus.

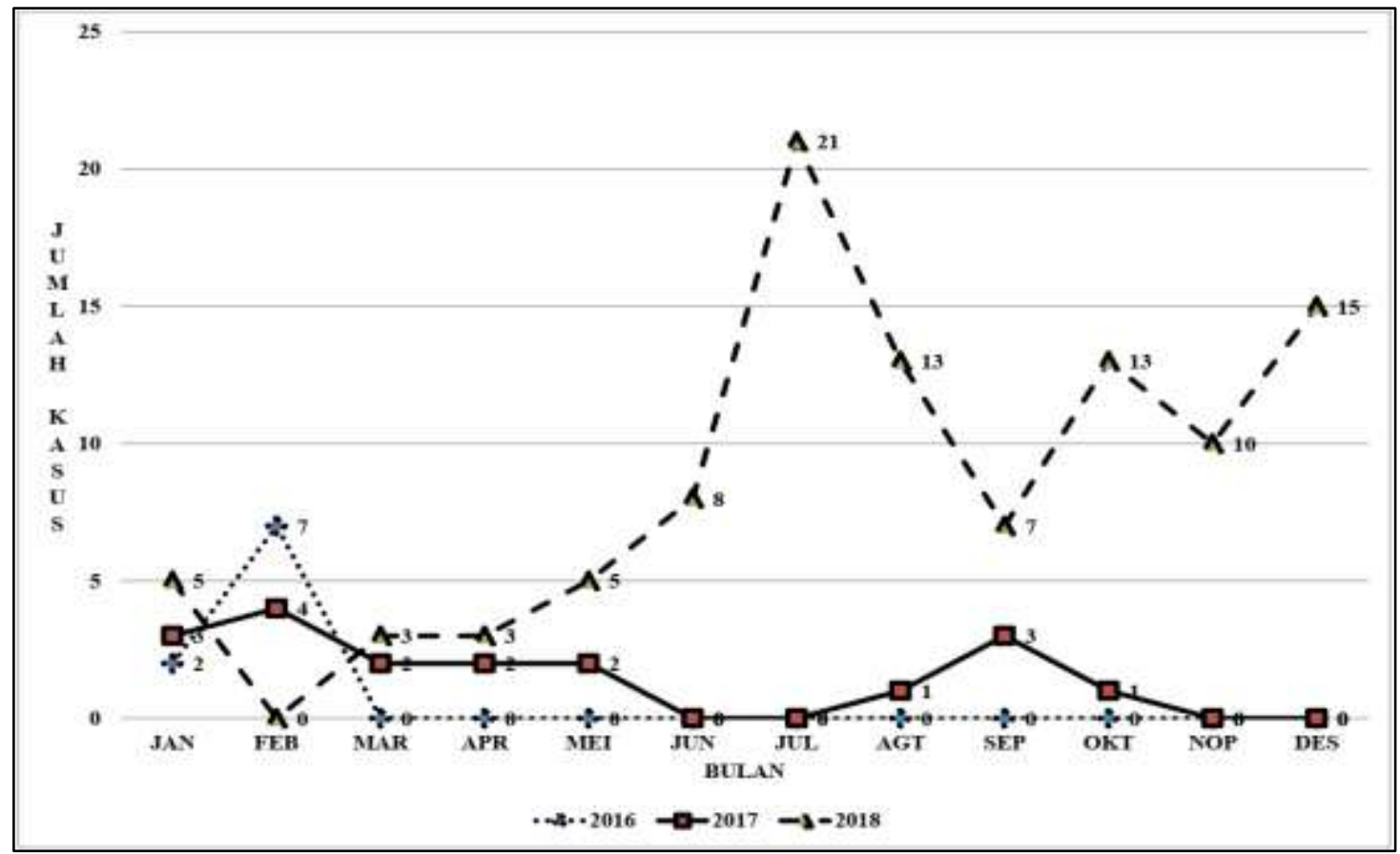

Gambar 6. Distribusi penderita DBD berdasarkan waktu kejadian

Gambar 6 menunjukkan bahwa pada tahun 2016, kasus DBD hanya terjadi pada awal tahun (Januari-Februari) dimana kasus tertinggi ditemukan pada bulan Februari sebesar 7 kasus. Pada tahun 2017, kasus DBD terjadi pada bulan Januari-Mei kemudian muncul lagi pada Agustus-Oktober dimana kasus tertinggi ditemukan pada bulan 
Februari sebesar 4 kasus. Pada tahun 2018, kasus DBD terjadi sepanjang tahun (kecuali bulan Februari) dimana kasus tertinggi ditemukan pada bulan Juli sebanyak 21 kasus.

Trend/ kecenderungan kejadian DBD pada tahun 2016 dan 2017 terlihat mirip yaitu banyak terjadi di awal tahun dan mulai menurun pada akhir tahun. Hal ini berbeda jika dilihat pada tahun 2018. Pada tahun ini, kejadian DBD mengalami kecenderungan peningkatan pada pertengahan dan akhir tahun.

Kasus DBD di Indonesia biasanya terjadi pada musim hujan dimana semakin banyak tempat untuk nyamuk Aedes aegypti untuk berkembangbiak, namun akhir-akhir ini kasus DBD sering terjadi di awal bulan Januari. (Soegijanto, 2006) Hasil penelitian Safinah (2004) didapati bahwa proporsi penderita DBD Rawat Inap di RSUD Dr. Pirngadi tahun 2002 paling banyak pada bulan November (13,2\%) dan tahun 2003 paling banyak pada bulan September (36,6\%). Penelitian Mandriani (2009) diperoleh bahwa proporsi penderita DBD berdasarkan bulan terdapat pada bulan Januari dengan persentase $22,1 \%$.

Penelitian dari Ariati dan Anwar (2014) menunjukkan bahwa kejadian DBD cukup tinggi di bulan Januari - Maret pada tahun 2004 sampai 2007 dan mengalami peningkatan pada tahun 2008 sampai 2010 dengan jumlah kasus DBD rata-rata diatas 100 kasus setiap bulan dan ini terjadi sepanjang tahun. Hasil menunjukkan bahwa distribusi kejadian DBD selama kurun waktu 10 tahun (2002 sampai 2011) di Kota Bogor nampak berfluktuasi dan kejadian paling tinggi terjadi pada bulan Januari sampai Maret. Pada tahun 2008 kejadian DBD mulai mengalami peningkatan pada bulan Januari dan tertinggi pada bulan Juni. Kejadian DBD pada awal tahun cukup tinggi karena banyak terbentuk genangan-genangan air yang terjadi pada musim penghujan, sehingga menjadi habitat perkembangbiakan bagi jentik Aedes sp. Puncak curah hujan di kota Bogor terjadi pada bulan November hingga Maret sedangkan hari hujan mulai meningkat sejak bulan September.

\section{PENUTUP}

Kesimpulan penelitian ini yaitu penderita DBD di Kabupaten Minahasa tahun 2016-2018 mengalami peningkatan dimana paling banyak ditemukan pada umur 11-20 tahun dan berjenis kelamin perempuan. Berdasarkan hasil penelitian ini maka harus dilaksanakan upaya pengendalian secara terpadu yang melibatkan masyarakat, pemerintah, swasta dan akademisi. Selain itu, perlu dilakukan upaya promotif dan preventif terhadap masyarakat khususnya pada kelompok umur 11-20 tahun dan berjenis kelamin perempuan.

\section{DAFTAR PUSTAKA}

Akib AAP. Munasir Z. dan Kurniati N. 2008. Buku Ajar Alergi Imunologi Anak. Jakarta: IDAI: 9-50

Anders K.L., Nguyet N.M., Chau N.V., Hung N.T., Thuy T.T., Lien L.B., Farrar J., Wills B.,Hien T.T., Simmons C.P., 2011. Epidemiological Factors Associated with Dengue Shock Syndrome and Mortality in Hospitalized Dengue Patients in Ho Chi Minh City, Vietnam. The American Journal of Tropical Medicine and Hygiene 84(1): 127-134.

Ariati, J., \& Anwar, A. (2014). Model Prediksi Kejadian Demam Berdarah Dengue (DBD) Berdasarkan Faktor Iklim di Kota Bogor, Jawa Barat. Buletin Penelitian Kesehatan, 42 (4 Des), 249-256.

Arifin, N. F., Adi, M. S., \& Suhartono, S. (2017). Analisis spasial dan temporal demam berdarah dengue di Kota Tanjungpinang tahun 2016 (Doctoral dissertation, School of Postgraduate).

Batubara JRL. Tridjaja AAP. dan Pulungan AB. 2010. Buku Ajar Endokrinologi Anak. Jakarta: IDAI: 1-29 
Dardjito, E., Yuniarno, S., Wibowo, C., DL, A. S., \& Dwiyanti, H. (2008). Beberapa Faktor Risiko yang Berpengaruh terhadap Kejadian Penyakit Demam Berdarah Dengue (DBD) di Kabupaten Banyumas. Media Penelitian dan Pengembangan Kesehatan, 18 (3 Sept).

Dinas Kesehatan Kabupaten Minahasa. 2018. Prevalensi Kejadian DBD di Kabupaten Minahasa tahun 2016-2018. Tondano

Hakim L dan Kusnandar AJ. (2012) Hubungan status gizi dan kelompok umur dengan status infeksi virus dengue. Pengandaran Kab. Ciamis: Loka Penelitian dan Pengembangan Penyakit Bersumber Binatang; 2012: 34-45

Mandriani E., 2009. Karakteristik Penderita Demam Berdarah (DBD) Yang Mengalami Dengue Shock Syndrome (DSS) Rawat Inap Di RSU Dr. Pirngadi Medan Tahun 2008. Skripsi, FKM USU, Medan.

Nelli, S. (2007) Hubungan status gizi dengan kejadian renjatan pada penderita anak demam berdarah dengue pada periode Januari - Juni 2006 di RSUD Dr. Djamil Padang. Skripsi. UNAND. Padang

Permatasari, D. Y., Ramaningrum, G., \& Novitasari, A. (2013). Hubungan Status gizi, Umur, dan Jenis kelamin dengan Derajat Infeksi Dengue pada Anak. Jurnal Kedokteran Muhammadiyah, 2(1).

Riyanto, A. 2011. Aplikasi Metodologi Penelitian Kesehatan. Yogyakarta: Nuha Medika

Safinah., 2004. Karakteristik Penderita Demam Berdarah Dengue (DBD) Rawat Inap di RSUD Dr. Pirngadi Medan Tahun 2002-2003. Skripsi,FKM USU, Medan

Simanjuntak, P. M. B. (2016). Karakteristik Penderita Demam Berdarah Dengue (DBD) dengan Dengue Shock Syndrome (DSS) dan Non DSS di RSUD Dr. Pirngadi Medan Tahun 2013-2015.

Soedarmo SPS. Garna H. dan Hadinegoro SRS. Satari HI. 2008. Buku Ajar Infeksi \& Pediatri Tropis. Jakarta: IDAI: 155-181

Soedarto. 2012. Demam Berdarah Dengue (Dengue Haemoohagic Fever). Jakarta: CV Sagung Seto

Soegijanto S., 2006. Demam Berdarah Dengue, Ed. 2. Airlangga University Press: Surabaya.

Sofro AU. Muchlis dan Anurogo. D. 2018. Praktis dan Jitu Atasi Penyakit Infeksi dan Problematika Kesehatan. Yogyakarta: Rapha Publihing

Sumampouw, O. J. (2019). Perubahan Iklim Dan Kesehatan Masyarakat. Deepublish.

Sumarmo, S.P. (1999) Masalah Demam Berdarah Dengue di Indonesia, Demam Beradah Dengue, Naskah Lengkap Pelatihan Bagi Pelatih Dokter Spesialis Anak dan Dokter Spesialis Dalam Tata Laksana Kasus DBD, Hal 5, Fakultas Kedokteran Universitas Indonesia, Jakarta. Depkes RI, Ditjen PPM \& PLP, 1998/1999

Supariasa IDN. Bakri B. dan Fajar I. 2012. Penilaian Status Gizi. Jakarta: EGC 